\title{
Development of a multiplex PCR assay for identification of Campylobacter coli, Campylobacter fetus, Campylobacter hyointestinalis subsp. hyointestinalis, Campylobacter jejuni, Campylobacter lari and Campylobacter upsaliensis
}

Correspondence

Wataru Yamazaki-Matsune wataru@iph.pref.osaka.jp

Received 26 April 2007

Accepted 9 July 2007
Wataru Yamazaki-Matsune, ${ }^{1}$ Masumi Taguchi, ${ }^{1}$ Kazuko Seto, ${ }^{1}$ Ryuji Kawahara, ${ }^{1}$ Kentaro Kawatsu, ${ }^{1}$ Yuko Kumeda, ${ }^{1}$ Miyoshi Kitazato, ${ }^{2}$ Masafumi Nukina, ${ }^{3}$ Naoaki Misawa ${ }^{4}$ and Teizo Tsukamoto ${ }^{1} \dagger$

${ }^{1}$ Division of Bacteriology, Osaka Prefectural Institute of Public Health, Osaka, Japan

${ }^{2}$ Yodogawa Christian Hospital, Osaka, Japan

${ }^{3}$ Microbiological Department, Kobe Institute of Health, Hyogo, Japan

${ }^{4}$ Department of Veterinary Public Health, Faculty of Agriculture, University of Miyazaki, Miyazaki, Japan

A multiplex PCR assay has been developed for the identification of the six common Campylobacter taxa associated with human gastroenteritis and/or septicaemia, namely Campylobacter coli, Campylobacter fetus, Campylobacter hyointestinalis subsp. hyointestinalis, Campylobacter jejuni, Campylobacter lari and Campylobacter upsaliensis. The assay was developed using a combination of newly designed and published primers. It provided a specific PCR product for each of the five Campylobacter species and the one subspecies, and each of the PCR products was sufficiently distinguished by a difference in size by agarose gel electrophoresis. On evaluation of efficacy with 142 Campylobacter strains, the assay correctly identified all strains as 1 of the 6 Campylobacter taxa. This multiplex PCR assay is a rapid, simple and practical tool for identification of the six Campylobacter taxa commonly associated with gastroenteritis and/or septicaemia in humans, and offers an effective alternative to conventional biochemical-based assays.

\section{INTRODUCTION}

Campylobacter is widely acknowledged as one of the most frequent causes of acute bacterial gastroenteritis in humans worldwide. Campylobacter jejuni and Campylobacter coli are the predominant cause of campylobacteriosis. Furthermore, Campylobacter fetus, Campylobacter hyointestinalis subsp. hyointestinalis, Campylobacter lari and Campylobacter upsaliensis have also been recognized as human pathogens, mainly causing gastroenteritis and/or septicaemia (Broczyk et al., 1987; Salama et al., 1992; Goossens et al., 1995; Moore et al., 2005; On, 2005). These four taxa would be underestimated because the

tPresent address: Graduate School of Life and Environmental Sciences, Osaka Prefecture University, Osaka, Japan.

The GenBank/EMBL/DDBJ accession numbers for the 16S rRNA sequences are AB301955-AB301967. isolation conditions for C. jejuni and C. coli (incubation at $42{ }^{\circ} \mathrm{C}$ on selective-ingredient-containing media) are inhibitory to certain strains of these four Campylobacter (Logan et al., 2001; Moore et al., 2005; On, 2005). The pathogenic role of the four taxa in humans is not well understood, but the clinical significance of these Campylobacter species as pathogens to humans should not be discounted.

Conventional biochemical-based assays for identification of Campylobacter species are time-consuming and laborious due to the fastidious growth requirements of these species and the paucity of informative biochemical characteristics. A rapid, simple and practical assay for the identification of Campylobacter species has been sought.

Several PCR assays designed using single primer sets to identify Campylobacter species have been developed (Linton et al., 1996; Inglis \& Kalischuk, 2003a). Although PCR assays provide more rapid identification of these 
species than conventional assays, investigation of unknown samples requires the separate identification of each Campylobacter species, extending identification time and increasing reagent costs.

Two recently developed multiplex PCR assays (Wang et al., 2002; Klena et al., 2004) offer the more sophisticated approach of simultaneous identification of Campylobacter species. Both are handicapped, however, by the inability to cover all the six common taxa associated with gastroenteritis and/or septicaemia in humans, namely C. coli, C. fetus, C. hyointestinalis subsp. hyointestinalis, C. jejuni, C. lari, and C. upsaliensis.

Here, using a combination of new and published primers, we have developed a rapid, simple and practical multiplex PCR assay for identification of the six common Campylobacter taxa associated with gastroenteritis and/or septicaemia in humans. Furthermore, we have also evaluated the effectiveness of this assay.

\section{METHODS}

Campylobacter strains. A total of 146 Campylobacter strains were used. Eighteen Campylobacter reference strains were obtained from international culture collections (superscript $\mathrm{T}$ designates a typestrain): C. coli JCM $2529^{\mathrm{T}}$ (Japan Collection of Micro-organisms); C. fetus subsp. fetus ATCC27374 ${ }^{\mathrm{T}}$ (American Type Culture Collection), GTC08732 (Gifu Type Culture Collection, Gifu, Japan), GTC08746, GTC11236 and GTC12267; C. fetus subsp. venerealis JCM $2528^{\mathrm{T}}$; Campylobacter helveticus ATCC51209 ${ }^{\mathrm{T}}$; C. hyointestinalis subsp. hyointestinalis ATCC $35217^{\mathrm{T}}$; C. hyointestinalis subsp. lawsonii CCIPH-1 (Culture Collection, Institute of Public Health, Osaka, Japan); C. jejuni subsp. doylei LMG8843 ${ }^{\mathrm{T}}$ (Culture Collection of the Laboratorium voor Microbiologie, University of Ghent); C. jejuni subsp. jejuni LMG8841 ${ }^{\mathrm{T}}$, CCUG8077 (Culture Collection, University of Göteborg) and JCM2013; C. lari JCM $2530^{\mathrm{T}}$; Campylobacter mucosalis ATCC $43264^{\mathrm{T}}$; Campylobacter sputorum ATCC $35980^{\mathrm{T}}$; and C. upsaliensis ATCC $43954^{\mathrm{T}}$. A total of 128 Campylobacter isolates were obtained from clinical and environmental sources between 1988 and 2006 in Hyogo, Miyazaki and Osaka, Japan, as follows: 48 C. jejuni subsp. jejuni isolates from clinical sources $(n=25)$, poultry $(n=15)$, seagull faeces $(n=7)$ and puppy faeces $(n=1) ; 25$ C. fetus subsp. fetus isolates from cattle livers $(n=16)$ and clinical sources $(n=9) ; 20$ C. coli isolates from clinical sources $(n=15)$, pigs $(n=3)$ and poultry $(n=2) ; 15$ C. upsaliensis isolates from puppy faeces $(n=9)$ and adult dog faeces $(n=6) ; 10 \mathrm{C}$. lari isolates from seagull faeces $(n=9)$ and an unknown source $(n=1)$; and 10 C. hyointestinalis subsp. hyointestinalis from simian faeces $(n=5)$, cattle faeces $(n=4)$ and turtle faeces $(n=1)$.

Non-Campylobacter strains. Seven non-Campylobacter reference strains were obtained from international culture collections (Arcobacter butzleri ATCC49616 ${ }^{\mathrm{T}}$; Arcobacter cryaerophilus ATCC $43158^{\mathrm{T}}$; Arcobacter skirrowii ATCC $51132^{\mathrm{T}}$; Escherichia coli ATCC25922 and ATCC35218; Pseudomonas aeruginosa ATCC27853; and Staphylococcus aureus subsp. aureus ATCC25923). Fifteen nonCampylobacter isolates were obtained from clinical sources (five Helicobacter pylori isolates: and one isolate each of Aeromonas sobria, Aeromonas hydrophila, Providensia alcalifaciens, Salmonella Enteritidis, Shigella flexneri 1a, Shigella sonnei, Vibrio cholerae O1 Ogawa cholera-toxin positive, Vibrio fluvialis, Vibrio mimicus and Vibrio parahaemolyticus O3:K6 thermostable direct haemolysin positive).
Storage and culture conditions. All Campylobacter, Arcobacter and Helicobacter strains were stored in Brucella broth containing $10 \%$ $(\mathrm{v} / \mathrm{v})$ horse serum and $10 \%(\mathrm{v} / \mathrm{v}) \mathrm{DMSO}$ at $-80{ }^{\circ} \mathrm{C}$ until required. They were grown on blood agar supplemented with $5 \%$ (v/v) lysed horse blood, and incubated for 2-3 days in a microaerobic atmosphere, except H. pylori, which was incubated for 7-10 days. Microaerobic conditions were generated with an AnaeroPack MicroAero (Mitsubishi Gas Chemical), which maintained an atmosphere of approximately $8 \% \mathrm{O}_{2}, 7 \% \mathrm{CO}_{2}$ and $85 \% \mathrm{~N}_{2}$. All strains were grown at $37{ }^{\circ} \mathrm{C}$ except $A$. cryaerophilus, which was grown at $30{ }^{\circ} \mathrm{C}$. Other bacterial strains were stored in cooked meat broth at room temperature until required, and grown on blood agar and cultured overnight at $37{ }^{\circ} \mathrm{C}$ in aerobic conditions.

Multiplex PCR assay. Bacterial DNA was extracted as previously described (Misawa et al., 2002) with slight modifications. A single loopful of culture was inoculated in $50 \mu \mathrm{l} \mathrm{NaOH}(25 \mathrm{mM})$ in a $1.5 \mathrm{ml}$ microcentrifuge tube using a disposable loop ( $1 \mathrm{~mm}$ diameter), and the cell mixture was heated at $100{ }^{\circ} \mathrm{C}$ for $10 \mathrm{~min}$. After neutralization with $50 \mu \mathrm{l}$ tris/ $\mathrm{HCl}$ buffer $(80 \mathrm{mM}, \mathrm{pH} 7.5)$, cell debris was pelleted by centrifugation at $20000 \mathrm{~g}, 4{ }^{\circ} \mathrm{C}$, for $5 \mathrm{~min}$, and the supernatant was used as template DNA. The assay was developed using a combination of newly designed and previously reported primers in consideration of the size of the PCR product and annealing temperature. Three primers were designed from sequences submitted to GenBank with Primer Express software version 2.0 (Applied Biosystems). Details of these primers are given in Table 1. The final multiplex PCR comprised: $1 \mu \mathrm{l}$ template DNA; $0.2 \mu \mathrm{M}$ primers C412F, C1228R, C-1, C-3, CC18F, CC519R, CU61F, CU146R, MG3F, CF359R, CLF, CLR, HYO1F and HYOFET23SR; and $0.5 \times \mathrm{Q}$ solution (Qiagen) in $1 \times$ multiplex PCR master mix (Qiagen). The final volume was adjusted to $25 \mu$ l.

DNA amplification was performed in a TaKaRa PCR Dice Gradient thermal cycler (TaKaRa Bio). The cycling conditions used were one cycle of $95{ }^{\circ} \mathrm{C}$ for $15 \mathrm{~min}, 25$ cycles each of $95{ }^{\circ} \mathrm{C}$ for $0.5 \mathrm{~min}, 58{ }^{\circ} \mathrm{C}$ for $1.5 \mathrm{~min}$ and $72{ }^{\circ} \mathrm{C}$ for $1 \mathrm{~min}$, and ending with a final extension time at $72{ }^{\circ} \mathrm{C}$ for $7 \mathrm{~min}$. Samples were held at $4{ }^{\circ} \mathrm{C}$ prior to analysis. Each reaction mixture was analysed by gel electrophoresis through $3 \%(\mathrm{w} / \mathrm{v})$ agarose in $1 \times \mathrm{TAE}$ buffer, and visualized by UV transillumination after staining with ethidium bromide.

Biochemical-based assays. All Campylobacter strains except 10 C. hyointestinalis subsp. hyointestinalis isolates, C. helveticus ATCC $51209^{\mathrm{T}}$, C. mucosalis ATCC $43264^{\mathrm{T}}$ and C. sputorum ATCC$35980^{\mathrm{T}}$ were biochemically identified by testing for the following characteristics according to the method of Nachamkin (2003): catalase and oxidase reactions; growth at 25 and $42{ }^{\circ} \mathrm{C}$ on blood agar; sodium hippurate hydrolysis; indoxyl acetate hydrolysis; and susceptibility to cephalotin and nalidixic acid (30 $\mu \mathrm{g}$ discs). C. fetus and $C$. hyointestinalis strains were tested for $\mathrm{H}_{2} \mathrm{~S}$ production on freshly prepared triple-sugar iron agar, and for tolerance to $1 \%(\mathrm{w} / \mathrm{v})$ glycine as described in published papers (On \& Holmes, 1991; On \& Vandamme, 1997). C. hyointestinalis strains were tested for tolerance to $1.5 \%(\mathrm{w} / \mathrm{v})$ bile according to the method of On \& Holmes (1991). C. helveticus ATCC $51209^{\mathrm{T}}$ was not tested for biochemical characteristics due to poor growth on blood agar. Ten C. hyointestinalis subsp. hyointestinalis isolates, C. mucosalis ATCC $43264^{\mathrm{T}}$ and C. sputorum ATCC $35980^{\mathrm{T}}$ were not tested for biochemical characteristics, as only extracted DNAs were obtained.

PCR assays. PCR assays were performed for 40 Campylobacter isolates that could not be identified by biochemical-based assay alone. A PCR assay (Linton et al., 1996) was carried out on 15 Campylobacter isolates to discriminate C. upsaliensis from $C$. helveticus, using C. upsaliensis ATCC43954 ${ }^{\mathrm{T}}$ and C. helveticus ATCC $51209^{\mathrm{T}}$ as positive controls. A second PCR assay (Wang et al., 
Table 1. Primer sequences used for the multiplex PCR assay and predicted sizes of PCR products

\begin{tabular}{|c|c|c|c|c|c|c|}
\hline Species & $\begin{array}{l}\text { Size } \\
(\text { bp })\end{array}$ & $\begin{array}{l}\text { Target } \\
\text { gene }\end{array}$ & $\begin{array}{c}\text { GenBank } \\
\text { accession no. }\end{array}$ & Primer & Sequence $\left(5^{\prime}\right.$ to $\left.3^{\prime}\right)$ & Reference or source \\
\hline $\begin{array}{l}\text { Genus } \\
\text { Campylobacter }\end{array}$ & 816 & $16 \mathrm{~S}$ rRNA & AL111168 & $\mathrm{C} 412 \mathrm{~F}$ & 5'-GGATGACACTTTTCGGAGC-3' & Linton et al. (1996) \\
\hline & & & & $\mathrm{C} 1228 \mathrm{R}^{*}$ & 5'-CATTGTAGCACGTGTGTC-3' & Linton et al. (1996) \\
\hline $\begin{array}{l}\text { C. hyointestinalis } \\
\text { subsp. } \\
\text { hyointestinalis }\end{array}$ & 611 & $23 \mathrm{~S}$ rRNA & X67761 & HYO1F & 5'-ATAATCTAGGTGAGAATCCTAG-3' & Inglis \& Kalischuk (2003a) \\
\hline & & & & HYOFET23SR 5 & 5'-GCTTCGCATAGCTAACAT-3' & Inglis \& Kalischuk (2003a) \\
\hline C. coli & 502 & $a s k \dagger$ & AF017758 & $\begin{array}{l}\text { CC18F } \\
\text { CC519R }\end{array}$ & $\begin{array}{l}\text { 5'-GGTATGATTTCTACAAAGCGAG-3' } \\
\text { 5'-ATAAAAGACTATCGTCGCGTG-3' }\end{array}$ & $\begin{array}{l}\text { Linton et al. (1997) } \\
\text { Linton et al. (1997) }\end{array}$ \\
\hline C. fetus & 359 & $\operatorname{cst} A$ & AY158813 & $\begin{array}{l}\text { MG3F } \\
\text { CF359R }\end{array}$ & $\begin{array}{l}\text { 5'-GGTAGCCGCAGCTGCTAAGAT-3' } \\
5^{\prime} \text {-AGCCAGTAACGCATATTATAGTAG-3' }\end{array}$ & $\begin{array}{l}\text { Hum et al. (1997) } \\
\text { This study } \neq\end{array}$ \\
\hline C. lari & 251 & $\operatorname{gly} A$ & AF136495 & $\begin{array}{l}\text { CLF } \\
\text { CLR }\end{array}$ & $\begin{array}{l}\text { 5'-TAGAGAGATAGCAAAAGAGA-3' } \\
5^{\prime} \text {-TACACATAATAATCCCACCC-3' }\end{array}$ & $\begin{array}{l}\text { Wang et al. (2002) } \\
\text { Wang et al. (2002) }\end{array}$ \\
\hline C. upsaliensis & 86 & $\operatorname{lp} x A$ & AY598996 & $\begin{array}{l}\text { CU61F } \\
\text { CU146R }\end{array}$ & $\begin{array}{l}\text { 5'-CGATGATGTGCAAATTGAAGC-3' } \\
\text { 5'-TTCTAGCCCCTTGCTTGATG-3' }\end{array}$ & $\begin{array}{l}\text { This studyll } \\
\text { This studyll }\end{array}$ \\
\hline
\end{tabular}

${ }^{\star}$ Inglis \& Kalischuk (2003a) indicated a typographical error in the paper by Linton et al. (1996): primer 1288 should have read primer 1228. $\dagger$ Presumed to encode an aspartokinase gene by Linton et al. (1997). \$Designed from the sequence of AY598985, submitted to GenBank by Müller et al. (2003).

§Presumed to encode an oxidoreductase from the sequence of AL111168, submitted to GenBank by Parkhill et al. (2000). IIDesigned from the sequence of AY158813, submitted to GenBank by Klena et al. (2004).

2002) was performed on 25 Campylobacter isolates to differentiate $C$. coli from hippurate-negative C. jejuni, using C. coli JCM2529 ${ }^{\mathrm{T}}$ and $C$. jejuni subsp. jejuni $\mathrm{LMG} 841^{\mathrm{T}}$ as positive controls.

Sequencing analysis. Sequencing analysis was performed on ten $C$. hyointestinalis subsp. hyointestinalis isolates, two C. fetus subsp. fetus isolates grown at $42{ }^{\circ} \mathrm{C}$ and C. hyointestinalis subsp. lawsonii CCIPH1 for identification. Primers and methods used for PCR amplification, purification of PCR products, and sequencing of $16 \mathrm{~S}$ rRNA gene PCR products were performed according to the method of Harrington \& On (1999). The sequences were determined with an ABI Prism 310 genetic analyser (Applied Biosystems) and compared with the National Center for Biotechnology Information GenBank database for best matches.

\section{RESULTS AND DISCUSSION}

Here, we report a new multiplex PCR assay for identification of the six common Campylobacter taxa associated with human gastroenteritis and/or septicaemia, namely C. coli, C. fetus, C. hyointestinalis subsp. hyointestinalis, C. jejuni, C. lari and C. upsaliensis. This assay provided a specific PCR product for each of the six Campylobacter taxa, and each of the PCR products was sufficiently distinguished by a difference in size by agarose gel electrophoresis. The genusspecific primer set based on the 16s rRNA gene provided PCR products for all Campylobacter strains tested. The assay correctly identified all 142 Campylobacter strains tested as 1 of the 6 Campylobacter taxa. C. fetus and C. jejuni were identified regardless of subspecies. The results of multiplex PCR assays agreed completely with those of the conventional biochemical basis, and supplementary PCR assays and sequencing analysis. Non-specific PCR products were not obtained from any Campylobacter strains used. No PCR products were obtained from any of the 22 non-Campylobacter strains.

The multiplex PCR assay was initially developed and optimized using 18 Campylobacter reference strains. PCR products with the predicted sizes were obtained from all 18 strains, and each of the PCR products was successfully distinguished using approximately 70-200 bp intervals from a range of more than $700 \mathrm{bp}$. The species-specific primer sets for C. coli, C. fetus, C. hyointestinalis subsp. hyointestinalis, C. jejuni, C. lari and C. upsaliensis were highly specific for the corresponding Campylobacter taxa. Representative PCR results are shown in Fig. 1.

To evaluate the effectiveness of the multiplex PCR assay, all Campylobacter isolates previously identified by conventional biochemical-based identification were tested, except for 10 C. hyointestinalis subsp. hyointestinalis isolates. Although these biochemical-based assays successfully identified 76 of 118 isolates, 42 isolates required additional PCR assay or sequencing analysis to compensate for the low differential power of the biochemical-based assays. The results of the biochemical-based and additional PCR assays are shown in Table 2. Sequencing analysis of 16S rRNA gene PCR products was performed on ten C. hyointestinalis subsp. hyointestinalis isolates, two C. fetus subsp. fetus 


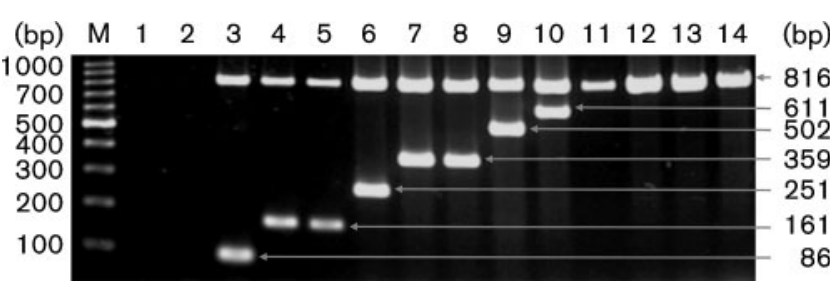

Fig. 1. $P C R$ products obtained by multiplex PCR assay for identification of the six Campylobacter taxa. Lanes: M, DNA size markers (TaKaRa Bio); 1, A. butzleri ATCC49616 ${ }^{\top} ; 2$, E. coli ATCC25922; 3, C. upsaliensis ATCC43954 ${ }^{\top}$; 4, C. jejuni subsp. doylei LMG8843 ${ }^{\top} ; 5$, C. jejuni subsp. jejuni LMG8841 ${ }^{\top}$; 6, C. lari JCM2530' ; 7, C. fetus subsp. fetus ATCC $27374^{\top} ; 8$, C. fetus subsp. venerealis JCM2528 ${ }^{\top} ;$ 9, C. coli $\mathrm{JCM}^{2} 529^{\mathrm{T}} ; 10, \mathrm{C}$. hyointestinalis subsp. hyointestinalis ATCC $35217^{\top} ; 11, C$. helveticus ATCC51209 ${ }^{\mathrm{T}} ; 12$, C. hyointestinalis subsp. lawsonii $\mathrm{CCIPH}-1$; 13, C. mucosalis ATCC $43264^{\top} ; 14$, C. sputorum ATCC $35980^{\top}$.

isolates grown at $42{ }^{\circ} \mathrm{C}$, and $C$. hyointestinalis subsp. lawsonii CCIPH-1. The obtained sequences gave lengths of 1283-1384 bp. The analysed sequences revealed one set of five isolates that were identical and one set of three isolates that were identical. Four different sequences best matched those of C. hyointestinalis subsp. hyointestinalis, and each of the best GenBank matches were 99.7\% (AF097690), $99.6 \%$ (AF097689), 98.2\% (AF097681) and 98.1\% (AF097682). Two isolates sequences were identical and matched completely with C. fetus subsp. fetus (AY621110). CCIPH-1 strain best matched C. hyointestinalis subsp. hyointestinalis (AF097687) at $99.6 \%$.

To date, two multiplex PCR assays for the identification of Campylobacter species have been reported. The first, based on the lpxA gene (Klena et al., 2004), is not practical for routine application owing to its relatively poor ability to distinguish four PCR products with less than $200 \mathrm{bp}$, while the second, developed for the identification of five Campylobacter species (Wang et al., 2002), has been shown to be unsuitable for the identification of $C$. fetus subsp. fetus (Willoughby et al., 2005). Furthermore, in our preliminary study, this second multiplex PCR assay failed to amplify PCR products in 2 of 30 C. fetus subsp. fetus isolates and in 10 of 16 C. upsaliensis isolates. Negative results for C. fetus subsp. fetus and C. upsaliensis were obtained from GTC12267 (an unknown source) and an isolate of one symptomatic patient, and from isolates of adult dog and puppy faeces, respectively (data not shown).

We therefore developed a new multiplex PCR assay using a combination of primers newly designed for $C$. fetus and $C$. upsaliensis with those already reported for C. coli, $C$. hyointestinalis subsp. hyointestinalis, C. jejuni, C. lari and genus Campylobacter. A C. fetus primer set was obtained from the sequence of the cstA gene (Hum et al., 1997; Müller et al., 2003). While the forward primer was as reported, the reverse primer was newly designed with shorter PCR products. A C. upsaliensis primer set was newly designed from the sequence of the lpxA gene (Klena et al., 2004) to allow an increase in annealing temperature and to avoid cross-reaction with a taxonomic neighbour species, C. helveticus. We adopted a C. coli primer set based on the putative aspartokinase gene (Linton et al., 1997) on the basis of the confirmed $100 \%$ specificity of this set (On \& Jordan, 2003). A C. hyointestinalis subsp. hyointestinalis primer set based on the 23S rRNA gene and a C. lari primer set based on the glyA gene were adopted owing to their excellent specificity (Inglis \& Kalischuk, 2003a; Wang et al., 2002). A C. jejuni primer set based on the putative oxidoreductase gene (Wang et al., 1992) was adopted, since no previously reported primer set based on the $c e u E$, the hipO, the mapA or 23S rRNA gene has shown $100 \%$ accuracy in the identification of C. jejuni (On \& Jordan, 2003). A genus-specific primer set based on the $16 \mathrm{~S}$ rRNA gene was used as an internal positive control to monitor the PCRs of Campylobacter species.

Among other taxa, C. helveticus and C. hyointestinalis subsp. lawsonii, are closely related to $C$. upsaliensis and $C$. hyointestinalis subsp. lawsonii at the genetic or biochemical characteristic levels, respectively (On, 2005), thus their discernment from the six other taxa targeted in the PCR assay is critical. The inability of $C$. helveticus to grow on potato starch agar or to reduce selenite are the only known phenotypic characteristics that distinguish it from $C$. upsaliensis (On, 2005). Since these tests are not routinely used, a species-specific PCR assay was developed to prevent the confusion of C. helveticus and C. upsaliensis (Linton et al., 1996). Accurate subspeciation of C. hyointestinalis subsp. hyointestinalis and C. hyointestinalis subsp. lawsonii requires sequencing analysis of the $16 \mathrm{~S}$ rRNA gene owing to the existence of atypical isolates (On \& Vandamme, 1997; Harrington \& On, 1999). However, our multiplex PCR assay provided both genus-specific and species-specific bands for the six Campylobacter taxa, but only the genus-specific band for the C. hyointestinalis subsp. lawsonii and C. helveticus strains indicating that our multiplex PCR assay clearly differentiated $C$. helveticus and C. hyointestinalis subsp. lawsonii from the six other Campylobacter taxa. Campylobacter concisus has been implicated in human periodontal disease (Macuch \& Tanner, 2000). Although this species has also been isolated from cases of diarrhoea in humans at a frequency resembling $C$. jejuni in some regions (Lastovica \& Skirrow, 2000; Engberg et al., 2000), they may also be isolated from healthy control patients at a similar rate (Van Etterick et al., 1996). The pathogenicity of this species is controversial (On, 2005). To the best of our knowledge, $C$. concisus has never been isolated from cases of diarrhoea in humans, nor from veterinary and environmental sources in Japan. Thus, we could not collect isolates of C. concisus. We assume detection value of $C$. concisus would be low, which is the reason for not considering C. concisus in our assay design.

Various case reports, such as isolation cases of non- $C$. jejuni and non-C. coli campylobacters from humans (On, 2005), mixed infection with two Campylobacter species 
Table 2. Campylobacter strains used, and results of biochemical characteristics and PCR assays

\begin{tabular}{|c|c|c|c|c|c|c|c|c|c|c|c|c|c|}
\hline \multirow[t]{2}{*}{ Species } & \multirow{2}{*}{$\begin{array}{c}\text { Size of } \\
\text { products } \\
(\mathbf{b p})^{\star}\end{array}$} & \multirow[t]{2}{*}{ Catalase } & \multirow[t]{2}{*}{ Oxidase } & \multicolumn{2}{|c|}{ Growth at: } & \multicolumn{2}{|c|}{ Hydrolysis of: } & \multicolumn{2}{|c|}{ Resistance to: } & \multirow{2}{*}{$\begin{array}{c}\mathrm{H}_{2} \mathrm{~S} / \mathrm{TSI} \\
\text { production }\end{array}$} & \multicolumn{2}{|c|}{ Tolerance to: } & \multirow{2}{*}{$\begin{array}{l}\text { Additional } \\
\text { PCRs }\end{array}$} \\
\hline & & & & $25^{\circ} \mathrm{C}$ & $42{ }^{\circ} \mathrm{C}$ & Hippurate & $\begin{array}{l}\text { Indoxyl } \\
\text { acetate }\end{array}$ & Cephalotin & $\begin{array}{c}\text { Nalidixic } \\
\text { acid }\end{array}$ & & $\begin{array}{c}\text { Glycine } \\
(1 \%)\end{array}$ & $\begin{array}{c}\text { Bile } \\
(1.5 \%)\end{array}$ & \\
\hline $\begin{array}{l}\text { C. jejuni subsp. jejuni } \\
(n=51)\end{array}$ & 816,161 & + & + & - & + & $\mathrm{V}(46 / 51)$ & + & $\mathrm{R}$ & $\mathrm{V}(5 / 51)$ & ND & $\mathrm{ND}$ & ND & CJ $(6 / 6)$ \\
\hline $\begin{array}{l}\text { C. jejuni subsp. doylei } \\
(n=1)\end{array}$ & 816,161 & + & + & - & - & + & + & $S$ & $S$ & $\mathrm{ND}$ & ND & $\mathrm{ND}$ & $\mathrm{ND}$ \\
\hline $\begin{array}{l}\text { C. fetus subsp. fetus } \\
(n=30)\end{array}$ & 816,359 & + & + & + & $\mathrm{V}(2 / 30)$ & - & - & $S$ & $\mathrm{R}$ & - & + & $\mathrm{ND}$ & $\mathrm{ND}$ \\
\hline $\begin{array}{l}\text { C. fetus subsp. venerealis } \\
(n=1)\end{array}$ & 816,359 & + & + & + & - & - & + & S & $S$ & - & - & $\mathrm{ND}$ & $\mathrm{ND}$ \\
\hline C. $\operatorname{coli}(n=21)$ & 816,502 & + & + & - & + & - & + & $\mathrm{R}$ & $\mathrm{V}(12 / 21)$ & ND & $\mathrm{ND}$ & ND & $\mathrm{CC}$ \\
\hline C. upsaliensis $(n=16)$ & 816,86 & - & + & - & $\mathrm{V}(14 / 16)$ & - & + & S & $\mathrm{V}(6 / 16)$ & ND & ND & $\mathrm{ND}$ & $\mathrm{CU}$ \\
\hline C. lari $(n=11)$ & 816,251 & + & + & - & + & - & - & $\mathrm{R}$ & $\mathrm{R}$ & $\mathrm{ND}$ & $\mathrm{ND}$ & $\mathrm{ND}$ & $\mathrm{ND}$ \\
\hline $\begin{array}{l}\text { C. hyointestinalis subsp. } \\
\text { hyointestinalis isolates } \\
(n=10)\end{array}$ & 816,611 & $\mathrm{ND}$ & $\mathrm{ND}$ & $\mathrm{ND}$ & $\mathrm{ND}$ & $\mathrm{ND}$ & $\mathrm{ND}$ & $\mathrm{ND}$ & $\mathrm{ND}$ & $\mathrm{ND}$ & ND & $\mathrm{ND}$ & $\mathrm{ND}$ \\
\hline $\operatorname{ATCC} 35217^{\mathrm{T}}(n=1)$ & 816,611 & + & + & + & + & - & - & $S$ & $\mathrm{R}$ & $+\dagger$ & + & + & ND \\
\hline C. helveticus $(n=1)$ & 816 & $\mathrm{ND}$ & ND & - & + & $\mathrm{ND}$ & $\mathrm{ND}$ & $\mathrm{ND}$ & $\mathrm{ND}$ & ND & $\mathrm{ND}$ & $\mathrm{ND}$ & CHEL \\
\hline $\begin{array}{l}\text { C. hyointestinalis subsp. } \\
\text { lawsonii }(n=1)\end{array}$ & 816 & + & + & - & + & - & - & $S$ & $\mathrm{R}$ & $+\ddagger$ & - & - & $\mathrm{ND}$ \\
\hline C. mucosalis $(n=1)$ & 816 & $\mathrm{ND}$ & ND & $\mathrm{ND}$ & $\mathrm{ND}$ & $\mathrm{ND}$ & ND & $\mathrm{ND}$ & $\mathrm{ND}$ & ND & ND & $\mathrm{ND}$ & $\mathrm{ND}$ \\
\hline C. sputorum $(n=1)$ & 816 & $\mathrm{ND}$ & ND & ND & $\mathrm{ND}$ & $\mathrm{ND}$ & ND & $\mathrm{ND}$ & $\mathrm{ND}$ & $\mathrm{ND}$ & $\mathrm{ND}$ & $\mathrm{ND}$ & ND \\
\hline $\begin{array}{l}\text { Non-Campylobacter } \\
\text { strains }(n=22) \S\end{array}$ & - & ND & $\mathrm{ND}$ & ND & $\mathrm{ND}$ & $\mathrm{ND}$ & ND & $\mathrm{ND}$ & $\mathrm{ND}$ & $\mathrm{ND}$ & $\mathrm{ND}$ & $\mathrm{ND}$ & ND \\
\hline
\end{tabular}

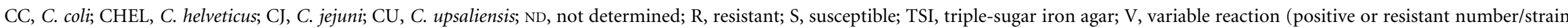
number tested); + , positive reaction; - , negative reaction.

${ }^{*}$ Results of the present multiplex PCR assay.

$†$ Trace $\mathrm{H}_{2} \mathrm{~S}$ production.

‡Copious $\mathrm{H}_{2} \mathrm{~S}$ production.

$\S$ Details of the strains are described in Methods. 
(Lawson et al., 1999), a severe meningitis outbreak caused by C. fetus (Morooka et al., 1996) and a fatal case associated with C. lari (Werno et al., 2002), highlight the need for the rapid and accurate identification of the six common Campylobacter taxa implicated in human gastroenteritis and/or septicaemia. Furthermore, numerous studies suggest that exposure to farm animal faeces, river water, raw milk, poultry and livestock offal are the risk factors for such human gastroenteritis and septicaemia (Devane et al., 2005; Inglis \& Kalischuk, 2003a; Inglis et al., 2003b; Moore et al., 2005; Savill et al., 2001). To enable a comprehensive approach to the control of these illnesses, the application of our assay to veterinary and environmental microbiology use should not be difficult. This multiplex PCR assay described here provides a powerful tool for the identification of the six Campylobacter taxa.

\section{ACKNOWLEDGEMENTS}

We appreciate the advice and expertise of Dr S. Makino (Obihiro University Agriculture and Veterinary Medicine, Hokkaido, Japan). In addition, we would like to thank Dr Y. Morikawa (Morikawa Pediatric Clinic, Osaka, Japan), Mr I. Yoneda and Ms K. Fukushima (Suita Municipal Hospital, Osaka, Japan) for providing Campylobacter isolates. This work was supported, in part, by a grant-in-aid from the Ministry of Health, Labour and Welfare (H18Shokuhin-Ippan-003).

\section{REFERENCES}

Broczyk, A., Thompson, S., Smith, D. \& Lior, H. (1987). Water-borne outbreak of Campylobacter laridis-associated gastroenteritis. Lancet $\mathbf{1}$, 164-165.

Devane, M. L., Nicol, C., Ball, A., Klena, J. D., Scholes, P., Hudson, J. A., Baker, M. G., Gilpin, B. J., Garrett, N. \& Savill, M. G. (2005). The occurrence of Campylobacter subtypes in environmental reservoirs and potential transmission routes. J Appl Microbiol 98, 980-990.

Engberg, J., On, S. L., Harrington, C. S. \& Gerner-Smidt, P. (2000). Prevalence of Campylobacter, Arcobacter, Helicobacter, and Sutterella spp. in human fecal samples as estimated by a reevaluation of isolation methods for campylobacters. J Clin Microbiol 38, 286-291.

Goossens, H., Giesendorf, B. A., Vandamme, P., Vlaes, L., Van den Borre, C., Koeken, A., Quint, W. G., Blomme, W., Hanicq, P. \& Koster, D. S. (1995). Investigation of an outbreak of Campylobacter upsaliensis in day care centers in Brussels: analysis of relationships among isolates by phenotypic and genotypic typing methods. J Infect Dis 172, 1298-1305.

Harrington, C. S. \& On, S. L. W. (1999). Extensive $16 \mathrm{~S}$ rRNA gene sequence diversity in Campylobacter hyointestinalis strains: taxonomic and applied implications. Int J Syst Bacteriol 49, 1171-1175.

Hum, S., Quinn, K., Brunner, J. \& On, S. L. W. (1997). Evaluation of a PCR assay for identification and differentiation of Campylobacter fetus subspecies. Aust Vet J 75, 827-831.

Inglis, G. D. \& Kalischuk, L. D. (2003a). Use of PCR for direct detection of Campylobacter species in bovine feces. Appl Environ Microbiol 69, 3435-3447.

Inglis, G. D., Kalischuk, L. D. \& Busz, H. W. (2003b). A survey of Campylobacter species shed in faeces of beef cattle using polymerase chain reaction. Can J Microbiol 49, 655-661.
Klena, J. D., Parker, C. T., Knibb, K., Ibbitt, J. C., Devane, P. M., Horn, S. T., Miller, W. G. \& Konkel, M. E. (2004). Differentiation of Campylobacter coli, Campylobacter jejuni, Campylobacter lari, and Campylobacter upsaliensis by a multiplex PCR developed from the nucleotide sequence of the lipid A gene lpxA. J Clin Microbiol 42, 5549-5557.

Lastovica, A. J. \& Skirrow, M. B. (2000): Clinical significance of Campylobacter and related species other than Campylobacter jejuni and C. coli. In Campylobacter, 2nd edn, pp. 89-120. Edited by I. Nachamkin \& M. J. Blaser. Washington, DC: American Society for Microbiology.

Lawson, A. J., Logan, J. M., O’Neill, G. L., Desai, M. \& Stanley, J. (1999). Large-scale survey of Campylobacter species in human gastroenteritis by PCR and PCR-enzyme-linked immunosorbent assay. J Clin Microbiol 37, 3860-3864.

Linton, D., Owen, R. J. \& Stanley, J. (1996). Rapid identification by PCR of the genus Campylobacter and of five Campylobacter species enteropathogenic for man and animals. Res Microbiol 147, 707-718.

Linton, D., Lawson, A. J., Owen, R. J. \& Stanley, J. (1997). PCR detection, identification to species level, and fingerprinting of Campylobacter jejuni and Campylobacter coli direct from diarrheic samples. J Clin Microbiol 35, 2568-2572.

Logan, J. M., Edwards, K. J., Saunders, N. A. \& Stanley, J. (2001). Rapid identification of Campylobacter spp. by melting peak analysis of biprobes in real-time PCR. J Clin Microbiol 39, 2227-2232.

Macuch, P. J. \& Tanner, A. C. (2000). Campylobacter species in health, gingivitis, and periodontitis. J Dent Res 79, 785-792.

Misawa, N., Kawashima, K., Kawamoto, H. \& Kondo, F. (2002). Development of a combined filtration-enrichment culture followed by a one-step duplex PCR technique for the rapid detection of Campylobacter jejuni and C. coli in human faecal samples. J Med Microbiol 51, 86-89.

Moore, J. E., Corcoran, D., Dooley, J. S., Fanning, S., Lucey, B., Matsuda, M., McDowell, D. A., Mégraud, F., Millar, B. C., O'Mahony, R. \& other authors (2005). Campylobacter. Vet Res 36, 351-382.

Morooka, T., Umeda, A., Fujita, M., Matano, H., Fujimoto, S., Yukitake, K., Amako, K. \& Oda, T. (1996). Epidemiologic application of pulsed-field gel electrophoresis to an outbreak of Campylobacter fetus meningitis in a neonatal intensive care unit. Scand J Infect Dis 28, 269-270.

Müller, W., Hotzel, H. \& Schulze, F. (2003). Identification and differentiation of Campylobacter fetus subspecies using PCR. Dtsch Tierarztl Wochenschr 110, 55-59.

Nachamkin, I. (2003). Campylobacter and Arcobacter. In Manual of Clinical Microbiology, vol. 1, 8th edn, pp. 902-914. Edited by P. R. Murray, E. J. Baron J. H. Jorgensen, M. A. Pfaller \& R. H. Yolken. Washington, DC: American Society for Microbiology.

On, S. L. W. (2005): Taxonomy, phylogeny, and methods for the identification of Campylobacter species. In Campylobacter Molecular and Cellular Biology, pp. 13-42. Edited by J. M. Ketley \& M. E. Konkel. Norfolk: Horizon Bioscience.

On, S. L. W. \& Holmes, B. (1991). Effect of inoculum size on the phenotypic characterization Campylobacter species. J Clin Microbiol 29, 923-926.

On, S. L. W. \& Jordan, P. J. (2003). Evaluation of 11 PCR assays for species-level identification of Campylobacter jejuni and Campylobacter coli. J Clin Microbiol 41, 330-336.

On, S. L. W. \& Vandamme, P. (1997). Identification and epidemiological typing of Campylobacter hyointestinalis subspecies by phenotypic and genomic methods and description of novel subgroups. Syst Appl Microbiol 20, 238-247. 
Parkhill, J., Wren, B. W., Mungall, K., Ketley, J. M., Churcher, C., Basham, D., Chillingworth, T., Davies, R. M., Feltwell, T. \& other authors (2000). The genome sequence of the food-borne pathogen Campylobacter jejuni reveals hypervariable sequences. Nature 403, 665-668.

Salama, S. M., Tabor, H., Richter, M. \& Taylor, D. E. (1992). Pulsedfield gel electrophoresis for epidemiologic studies of Campylobacter hyointestinalis isolates. J Clin Microbiol 30, 1982-1984.

Savill, M. G., Hudson, J. A., Ball, A., Klena, J. D., Scholes, P., Whyte, R. J., McCormick, R. E. \& Jankovic, D. (2001). Enumeration of Campylobacter in New Zealand recreational and drinking waters. J Appl Microbiol 91, 38-46.

Van Etterijck, R., Breynaert, J., Revets, H., Devreker, T., Vandenplas, Y., Vandamme, P. \& Lauwers, S. (1996). Isolation of Campylobacter concisus from feces of children with and without diarrhea. J Clin Microbiol 34, 2304-2306.
Wang, R. F., Slavic, M. F. \& Cao, W. W. (1992). A rapid PCR method for direct detection of low numbers of Campylobacter jejuni. J Rapid Methods Autom Microbiol 1, 101-108.

Wang, G., Clark, C. G., Taylor, T. M., Pucknell, C., Barton, C., Price, L., Woodward, D. L. \& Rodgers, F. G. (2002). Colony multiplex PCR assay for identification and differentiation of Campylobacter jejuni, $C$. coli, C. lari, C. upsaliensis, and C. fetus subsp. fetus. J Clin Microbiol 40, 4744-4747.

Werno, A. M., Klena, J. D., Shaw, G. M. \& Murdoch, D. R. (2002). Fatal case of Campylobacter lari prosthetic joint infection and bacteremia in an immunocompetent patient. J Clin Microbiol 40, 1053-1055.

Willoughby, K., Nettleton, P. F., Quirie, M., Maley, M. A., Foster, G., Toszeghy, M. \& Newell, D. G. (2005). A multiplex polymerase chain reaction to detect and differentiate Campylobacter fetus subspecies fetus and Campylobacter fetus -species venerealis: use on UK isolates of C. fetus and other Campylobacter spp. J Appl Microbiol 99, 758-766. 